\title{
HENRIK BJELKE
}

\author{
Luna
}

Demonic frenzy, moping melancholy and Moon-struck madness.

Paradise Lost

Jeg befandt mig i en spændt tilstand, som om jeg ventede på at en ulykke skulle indtræffe, og jeg sagde til mig selv: jeg når at vågne op, før den er sket. Men af det faktum, at der ingen forandring i spændingen fandt sted, kunne jeg slutte, at jeg ikke var vågnet $\mathrm{op}$.

Derpå begyndte jeg at frygte for, at jeg ikke skulle kunne nå at vågne op inden ulykken, hvilken frygt - lagt sammen med spændingen - gjorde situationen næsten uudholdelig. Jeg kæmpede i søvnens tanker for at vågne op og m.a.o. for at få den afbrudt, fordi jeg vidste, der ville være hårdt brug for mig om få øjeblikke. Omsider vågnede jeg op og indså alt dette. Min datter græder i natten: $\mathbf{i}$ det øjeblik jeg har forstået min situation, hører jeg fra det andet rum min lille datters skrig, farer op og finder, at hun er faldet ud over kanten af sengen og nu er på gulvet, hvor hun - uden orienteringssans - er på vej ind under dobbeltsengen i søvne. Jeg når at gribe hende, stilne hendes gråd og få hende lagt på plads igen i den - synes det - altfor store seng.

Jeg skal have alt det skvalderkål op i dag, sagde min kone om morgenen. Sikke en energi. Hun havde allerede været hos bageren. Jeg så et kort øjeblik på avisen mens jeg, på trappen i solskinnet og med tillukkede øjne af søvn, drak en stor kop kaffe med varm mælk $i$ et eneste langvarigt lydløst sug akkompagneret af rolige dybe vejrtrækninger gennem næsen. Jeg gider aldrig have andet om morgenen. Solen spillede nysgerrigt overalt, ens øjenlåg mønstrede vildt $\mathbf{i}$ rødt og orange, den pillede også lidt ved gårsdagens hovedpinerester. Telefonen kimede, lillepigen løber ind, det er til hende selv, med sin høje klare stemme snakker hun med en lignende, forestiller jeg mig, symmetrisk stemme. Da hun siger farvel, lægger jeg rørt mærke til det omsorgsfulde tonefald, der afspejler hvad barnet har hørt, nemlig vi voksnes lidt sentimentale klang ved afskeder, så korte de end er. Åh, de forbandet pragtfulde børn, om lidt er de voksne. Drengen kommer ind med sit skateboard, hjelm, lilla trøje med et tocifret nummer på brystet, som øjensynlig skal kunne ses på en kilometers afstand, i racet selvfølgelig, albuebeskyttere, knæbeskyttere, høj klar snak om wheels, trucks, rampe, board, flasbhjelm, kammerat dit og dat, arrangementer, stævner, møder, sidste nye lraftudtryk, geskæftighed fra morgenstunden, oplagte unger, jeg er b-menneske opdager jeg, kan ikke følge med, men det bølger om mig, så er han væk, gennem sartgrønne transparente buske ser jeg knægtene glide til og fra 
nede på vejen, som lodretstående undersøiske fisk i alle de spraglede farver mellem gennemlyste vandplanter, de laver free style, power slide, kick flip, walk the board og kick tail på deres fibre flex board, legekammeraten på sit brede rampeboard (og naboens lille plagiat-af-de-r2-årige på sit lille hobie woody board). Jeg elsker ikke teknologi, men for børn har den skabt graciøse lege og dermed graciøse børn, en anatomiens motorfri fartoverskridelse. Fra højre hører jeg den lille pige lege med de andre (stereofoniske stemmer) klæ-ud, cirkus og skole i blandet terminologi, eller også er jeg et fjols, men det kører engageret afsted. Og min elskede ligger i rajgræs og skvalderkål til albuerne, står så lidt, ikke uden et ganske erotisk vrid $\mathbf{i}$ hoften $\mathbf{i}$ sine usexede havebukser, stryger en hårlok fra panden og ser på sit flere dage gamle resultat, den fine sunde muld omkring bærbuskene, nu sår hun lidt græs. Jo gu bliver det herligt. Og der er hele tiden noget at gøre. Selv skal jeg i dag skære roser, skære hæk ned, bære tjørnen til et bål, se at få det brændt af trods væden underneden $\mathrm{i}$ de mange blade fra plænen. Ikke siden året r880 en juli med så meget nedbør, har jeg ladet mig fortælle, altså ikke siden huset blev bygget. Og så er det sidste dag for 2. spinatsåning, da fuldmånen teoretisk skulle være på fra i dag. Er det ikke også i dag, vi går ind i Løven? Jeg skal sætte bambus og et grantræ. Først sidder jeg lidt og sunder mig. Denne her dag er lang, jeg kan mærke det allerede. Pludselig står min kone, drengen, den lille pige rejseklare foran mig.

Det havde jeg sgu da glemt. Er det i dag? Åh nej. De skal til Rørvig hos morfar og mormor. Det er også skønt, joda. Hun vil gerne i vandet, han vil gerne køre på rampe med Rip, Rap og Rup, og morfar har selvfølgelig lavet en karet til den lille røv, det havde jeg glemt. Tingene går videre, hurtigere end du aner. Skulle jeg tage med?

Nej, jeg orker det ikke i dag, tag selv afsted. Jeg kommer derop i morgen til frokost, ikke. Jo okay. Før jeg ser mig om, er de væk.

Som en anden mekanisme står jeg og vinker, mens de går ned mod bussen og bliver mindre, og drejer om hjørnet og efterlader en tom vej, sort asfalt blinkende $\mathbf{i}$ solskinnet, øde og tom (öd' und leer das Meer). Med en udadtil eftertænksom holdning (i hovedet: od’ $^{\prime}$ und leer) går jeg åndsfraværende tilbage til lågen, går op gennem parken, der nu synes enorm, op mod huset, der ligger knejsende deroppe på toppen af bakken med sin skifer, sine mørkerøde mursten, sit alpeudhæng, sin gamle historie, ingen nogensinde har gidet høre på.

Klokken er I.30, jeg sidder i opholdsstuen og drikker te. Jeg er netop vågnet efter at have sovet inde i det gammelrosa arbejdsværelse. Stuen her er et stort, hvidt rum med vinduer mod syd og vest, for hvilke der er trukket lysende men gennemsigtige hvide lærredsgardiner, der går helt ned til gulvet og hvis sider mødes nøjagtig på midten ifølge snoresystemet. De giver et behageligt douce lys og fraværet af alt overflødigt i dette rum, dets nøgenhed, beroliger mig, men făr mig af og til også til at føle mig fremmed. Der er noget havestue over dette meget smukke rum. Gulvets lyse ubehandlede træ, to flettede kurvestole flettet af helt blege siv eller blege solstråler. Duften af en stor buket røde bittesmå roser, det lysegrønne klaver, "planta-flower-child"-plakatens lysende gulgrønne farver, den saftgrønne sofa - vegetativt $\mathrm{i}$ alle måder. Det kunne være en af min barndoms festdage eller en af de dage, 
jeg tilbragte på ferier i en stor gammel villa hos nogle rare tanter på Frederiksberg, hvor jeg fik lov at gå og sidde som om alt var mit, drikke te nårsomhelst $i$ hvilkensomhelst af salonerne jeg ville. Men dette er vores stue, min egen stue, jeg kan næsten ikke tro det, men det er sandt og følelsen af fremmedhed forlader mig. Jeg overgiver mig til rummet, fylder det, gror op, er endelig atter $i$ et drivhus. Her vil jeg trives.

Jeg trækker med vilje ikke gardinerne fra, jeg har ikke brug for synet af det der ligger neden for parken. Den by, der omgiver mig, er mig i dag ligegyldig, men jeg undgår ikke at høre dens larm. Larmen kontrasterer på den anden side vældig godt netop mod rummet her, dets stilhed, lys, ro, dets enkelthed modsat alt det indviklede, som kører afsted andre steder. Glasdøren ind til hendes olivenfarvede værelse er slået op på vid gab så man ser den indbydende dobbeltseng lige midt i rummet. Det er hende, der har givet mig disse rum. Det er hende. Igennem rummet kommer pludselig en stor fugl flyvende, ikke vandret, men lodret, seende sig stædigt til siden, vingerne symmetrisk halvt udfoldet som et emblem forestillende en lilje.

Vrøvlet begynder med at tebladene kommer op igen af vasken. Da jeg går på wc og rykker efter mig, sker det samme der. Når jeg så rykker igen, tager den det, men når den er færdig med at gurgle, ånder den ud i en flodbølge, der kommer og kommer op og står som et klart bassin i wc-kummen. Jeg gider ikke bruge wcet i kælderen mer. Jeg er træt af det. Jeg bruger det oppe på 1. sal, når jeg skal tisse. Det andet skider jeg på. Jeg er ligeglad. Jeg sætter mig ned ved skrivebordet, det ser alligevel overskyet ud nu og småkoldt. Og så var det de kom, de lydløse barfodsgængere. Jeg vidste det. Pludselig var de lydløse englændere i huset. Det var et blødt chok, men jeg vidste, at dette her var det, man havde ment med udtrykket. Jeg skottede efter dem bag min ryg. Det var rigtignok. Det var de usandsynligt tynde, stornæsede, lodenfrakkebeklædte unge mænds pludselige tilstedeværelse allevegne, $i$ alle køjer, bag alle skabe, det var barfodsgængerne fra England. Gik altid barfodede. Havde store, sorte lodenfrakker på, lange og vide. Som store uskadelige insekter. Blide og flinke, men man indså aldrig hvorfor.

Naturligvis måtte jeg ringe efter slamsugningsvogn eller en teknisk ambulance af en eller anden art, når der var forstoppelse $\mathrm{i}$ rørene.

Himlen var blevet helt mørk. Det rør vel ikke Dem, spurgte jeg stemmen i telefonen. Hvad for noget? sagde stemmen. Han må have været vagthavende. Vejret! sagde jeg. Nej, vi kører i al slags vejr, sagde den vagthavende, han må have været udekørende. Jamen suger De også i al slags vejr? spurgte jeg, kan De ikke risikere at suge hele vejret ind, så kan det jo godt tage sin tid, inden man bliver færdig. Bare rolig, hr., vi kommer.

Her sidder jeg alene $\mathrm{i}$ et drama efter at de støjende børn og hun, min tilværelses nav, er rejst og har betroet mig huset til vagt over dets hemmeligheder, malkloakering og forstoppelse, der er eksploderet i obskøniteter af hidtil indbildt ubemærkethed, hvis læseren kan udholde stilen, selv kan jeg jo kun gasse mig i den rent foreløbigt, er der ikke noget der ligefrem hedder horror vacui? Noget må man stille op. De drog intetanende bort, mens månen forberedte sig på $\mathrm{i}$ et kort frygteligt in- 
termezzo at danne et større tilværelsesnav, jeg blev hurtigt overladt til nogle ukendte elementer, der lå på spring med deres uforudseelige men uforudsete omvæltninger, blot for at slå ned, her nu, hvor også tiden har forladt kastanietræets kugleformede hårkrone.

Og under zodiakens auspicier nede dybt under vort gotiske hus af tegl og skifer tilstoppedes så kloakerne som en indledende ouverture til mere fundamentale opbrudsmekanismer i dets sjælelige organisme. Har huse ikke sjæle, der vender sig $\mathrm{i}$ søvne gennem trappernes knagen, når konstellationen går fra Krebsens til Løvens tegn? (ligesom de sømænd der vender sig i søvne samtidig med at vinden går i luvart).

Og da omsider den tekniske ambulance, en høj surrealistisk mareridtsopfindelse af en bus med tromler, slanger, håndsving, kuskesæder og baldakiner, havde trukket sin fede glatte sortblå Loch Ness slange ind, efterlod den sin regning på tusind lroner.

For mit indre blik så jeg en lorteslange af stablede glimtende mønter af guld på ti meters bugtninger ned gennem denne ivrige ubændige, øjensynlig alt andet end stenhårde jord.

Det er nu klaret lidt op i vejret. Jeg har rodet i haven nogle timer. I parken finder jeg så, meget til min forbløffelse, noget jeg aldrig før har lagt mærke til, nemlig et gammelt træpissoir med træbåse. En lille gammel dværg er kommet i klemme i en pissebås sammen med en større type, de får dog øjensynligt begge tisset, jeg finder en ledig bås, men da jeg ser ned, ser jeg gråt blødt slam eller gammelt lort ligge på gulvet. Da jeg ser nærmere efter, ser jeg en fod. Det viser sig, at der bag båsene er et stort stykke med slam, nede i slammet ligger en fyr, man ser kun øjnene, han er helt begravet $\mathrm{i}$ lort. Han ligger helt passiv og modstandsløs, levende men initiativløs. Det synes på en eller anden måde at fremgå af hele situationen, at han ligger der, fordi han har valgt at ligge der. Det fremgår på en eller anden måde, at det er hans udtryk for tilfredsstillelse af en eller anden tilbøjelighed.

En indigneret, oprørt stemning baner sig vej i mig, da jeg opdager ham helt og fuldt gennem mudrede anelser, bange mistanker, sømmelighedens bundløsheder, en fornemmelse af at tanken synker $i$ og dykker hinsides al stabilitet, grænsen for det sandsynlige viger og viger endeløst nedad og udad.

Så ser jeg ham møjsommeligt rejse sig med langsomme værdige bevægelser og slæbe et vattæppe eller en kåbe af slam langt efter sig og stige op på en forhøjning til venstre med en stor udendørs seng eller sandkasse fyldt med vand eller pis. Han lægger sig med slamtæppet over sig i sengen selvom den er fuld af pis. Det er om muligt endnu værre. Man ser pludselig et glimt af hans nøgne brune overkrop.

Jeg styrter op mod huset, tilbage gennem parken, ind i huset og direkte op på taget. Med skærende lyde drejer skorstenene med vindhaner på. Flere steder er der, i stedet for en vindhane eller en røgkanal eller hvad sådan en hedder, sat tubaer og andre messingblæseinstrumenter på skorstenene. Nede ved havnen ser jeg nu den tekniske ambulance med sin store spole med kabel standse op ud for en lastpram, eller er det et kabel der er monteret på prammen, måske er den en af sandsuger- 
prammene, som holder sundet farbart, eller også er det slamsugerbilen, jeg kan næsten ikke se det. Skibet ligger fortøjet bagved den tekniske ambulance.

Solen skriger sit hvide lys ned over havnen, store skibe blinker i lyset og vugger, færger står ud og ind uafladeligt, masser af skolebørn og kadetter eller spejdere, almindelig travlhed, sammenstimlen. Et eller andet er ved at blive hejst op af vandet ombord på skibet, der er meget højt, ikke nogen almindelig pram, kan det være et krigsskib med alt det gear, taljer, reb, tovværk på ruller, store spoler med ledninger og kabler, kraner og wirer? Op af vandet hejses nu en menneskelignende figur. Må være fyren fra lortebadet, han hænger bundet om fødderne med tov og hovedet nedad. Må være gledet gennem åen i parken ud i havnebassinet, har han også været gennem kloaksystemet, tanken får mig til at gyse og jeg føler kvælningsfornemmelser i larynx og de carotide arterier, i halsens ganglie-kæder og i brachial plexus, åhr, han går mig på, må jeg så be om almindeligt TV. Han har været ved at synke $\mathrm{i}$ havnen og hejses nu op som en ting, det er måske det han har villet. Han er ikke livløs, men vrider sig som en fisk der er bidt på madding. Da han svinges op klasker han (med forsinket akustik) mod agterstavnen og rælingen på skibet.

Jeg går ned i parkens dyb og brænder haveaffald af resten af dagen. Det kan ikke brænde. Jeg prøver med benzin, blir selv halvvejs svedet af. Da alt andet er mislykkedes tager jeg en havesaks og to handsker af ru læder og forvilder mig ned i rosenkrattet, røde, lyserøde, hvide, gule, næsten orange, halvt afblomstrede, væltende ud med kronblade der allerede i kanterne er brune af overtid og jeg skærer en hel favnfuld og tager den ind $i$ en stor porcelænskumme, og så begynder de at dufte for mig, og jeg mindes 1965, Barbara, La beauté d'une rose, la beauté d'une rose.

Inden solen går ned er himlen lilla af nedbør. Heden, lummerheden, trykker ned over landskabet, min hovedpine varsler ikke godt. Der er et mærkeligt lys over haven. Så eksploderer det $\mathrm{i}$ øsregn, store som æg falder dråberne. Jeg blev en tung dråbe, (som de tunge dråber, der drypper en for en fra den sorte sky, der hanger over menneskets hoved: de forkynder, at lynet nu kommer, og de går som forkyndere til grunde, se, jeg er en lynets forkynder) en tung dråbe blå som dette quink fra skyen - men lynet selv er: Leo $i$ år under torden og lynild, under regnskyl, der dnukner $i$ haverne og trænger gennem taget på vort karpaterhus på bakken oprakt mod en truende himmel af lunefulde temperaturer og vedvarende materialer $\mathrm{i}$ vedvarende omskifteligheder, men med et stabilt punkt, der nu gør sig synligt i form af en lysende fuldmåne. Pludselig blæser det op, ringene har nået os, bølgerne, stormen har sat ind.

$\mathrm{Da}$ vi gik ind i Løvens tegn, blev bevidstheden klar over denne sjælens stormmåne, som førte mange slags fødsler med sig i sit magnetiske greb om fyldte vener og arterier, om utålmodige floder væltende i deres senge, om kabler af substanser og om hensovende dyriske, geologiske og atmosfæriske brunstkanaler. Halvt størlmede kloaker blev opblødt og gik i skred, som om Jorden menstruerede inden i alle dens sjæles indvolde. Landskabets slam i fugt blev mødt af den hvide nats lys af en tusind kilowatt suggestiv styrke, violet og højstemt $i$ unævnelige nuancer af evighed og titanhvidt $i$ hurtig puls. Imellem disse måneskybrud, disse månesyge anfald af knurrende gøende brølende gurglende stakåndede og månemagnetiske tide- 
vande ved flod sås flossede himles blafrende blege dødsfanger indvarsle endnu uhyrligere forekomster af Leo i LEO, geologiske tegn stræbende efter at nå op i selve tegnet. Ventende vulkaner op af hvis kratere nye fostre voksede støt og organisk som voks, side om side med vulkaner fyldte til bristepunktet med plasma, lava, lort, lymfe, blod og urin, flest med vold og ilt, flest i hjertehamren, fægtende puls og sitrende encefalografisk nervøsitet - for derpå at sætte af $i$ himmelsving og tredobbelte saltomortaler højt under dødsmånens sølvkugler-inden-i-hinanden i en større ekliptisk kugleverden: den majestætiske Løves vejrkatedral af kroner og kugler og stråler og sort uvejrsmusik rundt og rundt $i$ et rundende, rungende verdensbillede.

Og ilden og rosen er ét (det løber mig koldt ned ad ryggen). Haveaffaldet nærer Løvens ild. Regnvejret og tordenen nærer kraften i den indre omfordeling, det indre opbrud i fastgroede skorper. Stormen tørrer gavmildt men brutalt alt det druknede tørt igen, og væskerne får bevist deres standhaftighed under dens tyranniske ånde, som kun skulle røbe den magtfulde Leos indvarsling.

Ved at stige over sine bredder i sit forsøg på at følge månen, i sit forsøg på at nå frem til cirklens stilstand og fuldendthed, fik sjælen $\mathrm{i}$ overgangen mellem månefaser$n e, i$ overgangen mellem to af dyrekredsens tegn, en anelse om hvad den kom fra og hvad den gik til, om eliminering af fortiden og dens gods og om vage konturer af en fremtidig skikkelse, som blev inddraget $i$ dens skabelon af tidsfleksible ideer om sig selv: $\mathrm{i}$ begyndelsen en tomhed. I denne tomhed levede en uudtømmelig skat. Leo, rejs dig mod himlen, smelt mørket bort, slut cirklen og gyd din guldsperma $i$ en bue ned i månens natlige bændler af higende overfertile sølvfloder.

Note: "Luna" blev første gang trykt i samlingen Seles råb fra baghovedet, Arena I98I.

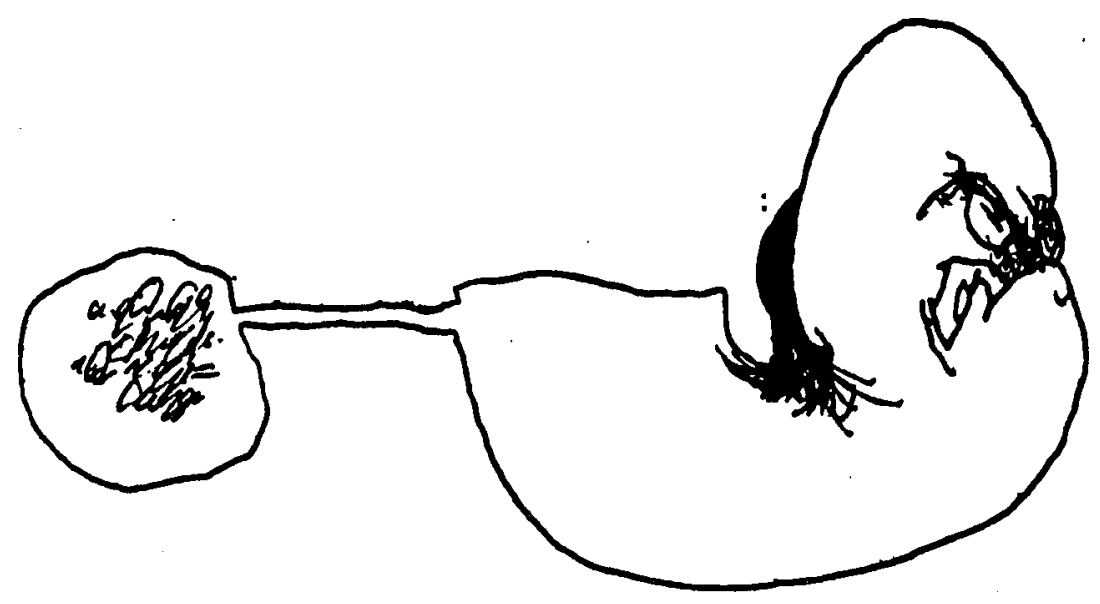

